\title{
The Clinical Dynamics of Pigment Loss
}

(A Study of $\mathbf{7}^{\mathrm{I}}$ lesions in Eastern Nigerians)

\author{
M. G. COR GOS, M.R.C.S., L.R.C.P., D.T.M. \& H. \\ (Formerly Medical Officer, Nigeria Leprosy Service)
}

Little attention seems to have been given to the clinical investigation of the development of hypopigmentcd skin patches in leprosy. This is understandable, since we are naturally concerned to try and diagnose these lesions as early as possible, and once they are diagnosed our interest is focussed on observing their resolution always, with the hope that this will be accelerated by therapy.

How does an area of normally pigmented skin change into a macule? According to Rogers and Muir, ${ }^{23}$ macules may appear by lateral spread, or they may already be of considerable size when first noticed. On the other hand Fite, ${ }^{11}$ referring particularly to tuberculoid skin plaques, considered that these lesions blossom forth as such with rare exceptions, and do not enlarge laterally to more than a slight degree. Rogers and Muir ${ }^{24}$ state that pigmentary loss in leprosy is due to interference with the function of the melanoblasts (the 'melanocytes' of contemporary histologists). It is much more commonly noticed in skins which contain a large amount of pigment. It is also seen typically in those lesions in which the melanincontaining cells of the stratum germinativum are most affected by the pathological process, that is to say, in those of tuberculoid and near tuberculoid conformation. In pure lepromatous lesions where a clear zone is interposed between the infiltrate and the basal layers of the epidermis, it tends to be absent or minimal.

In general, there is a close positive correlation between the location and timing of pigment loss and recovery, and the evolution and resolution of the epithelioid and giant cell granuloma. It was therefore considered that a study of the mode of onset of individual hypopigmented lesions might contribute to a better understanding of their microdynamics.

The functional relationship of pigment loss to the area of a skin patch theoretically involves three possibilities:-

I. Uniform or almost uniform loss of pigment over an increasing area,

2. Increasing loss of pigment over a static or almost static area and

3. Increasing loss of pigment over an increasing area.

An attempt was made, by questioning patients attending clinics and segregation villages in Rivers Province, Eastern Nigeria, to see if macules did in fact develop in these three ways, and if so whether such development could be related to sensation, the type of leprosy, the sex and maturity of the patient and the skin bacteriology.

\section{Method}

Water-colour diagrams were painted in burnt umber on strips of thick buff-tinted cartridge paper which were then sprayed with a shellac varnish. These were taken on routine tours of outstations.

Each strip consisted of seven squares on which were depicted different stages of a developing 'macule'. The expanding macules were shown as six roughly circular areas, the smallest being of I $\mathrm{cm}$. diameter, the other ones of diameters increasing by $\mathrm{I} \mathrm{cm}$. to the largest of $6 \mathrm{~cm}$. diameter. For the macules of almost static area, the first circle was of $5 \mathrm{~cm}$. diameter, the others increasing by $0.2 \mathrm{~cm}$. to the largest, again of $6 \mathrm{~cm}$. diameter. The lesion understudy was pointed out to the paticnt, who was then asked about its development (in the case of very young children, the parent was questioned). He was shown the diagrams in random order, and in his own language it was explained to him that a patch could get bigger while remaining the same colour, as in 1 . 


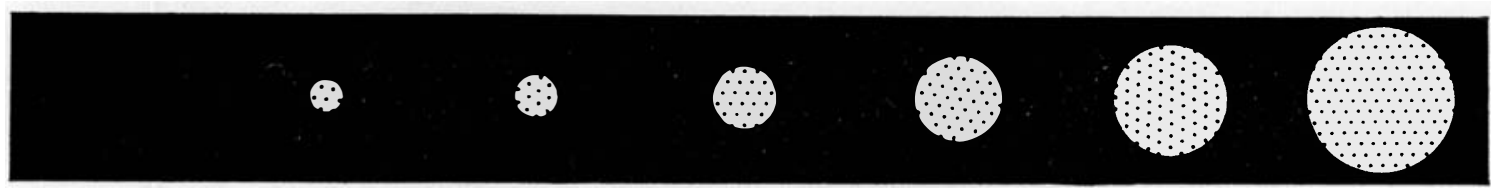

or it could remain almost the same size while bccoming paler as in 2 .

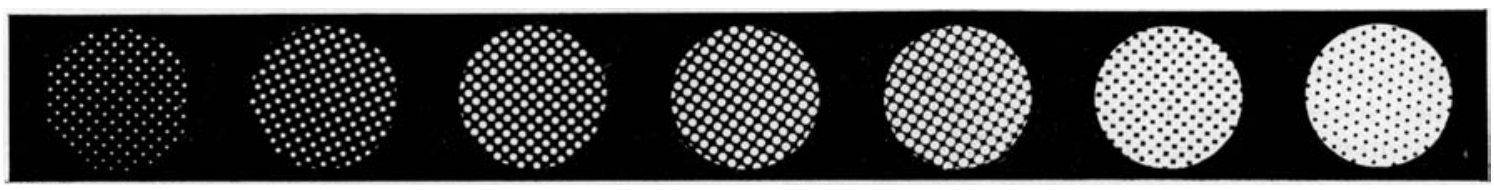

or it could get bigger and become paler at the same time, as in 3 .

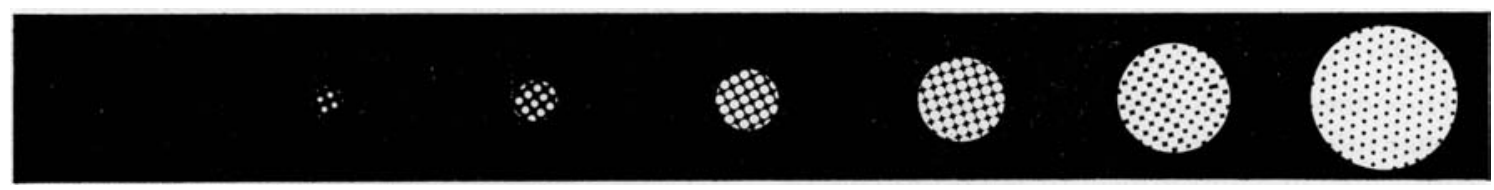

The patient was asked to try and remember in which category the patch under examination belonged.

In order to avoid confusion, the patients were not questioned about the history of sensory changes in the lesions, nor was any attempt made to ascertain their rate of development. For the same reason, the following kinds of lesion were excluded:- (a) Markedly raised ones, for example major tuberculoid and 'infiltrated dimorphous'; (b) Those showing only slight pigmentary loss, for example some of those included under $(a)$ above, and certain 'uncharacteristic' and near lepromatous macules; $(c)$ Those that appeared to be regaining their pigment when first seen, either by spontaneous centrifugal spread, or by uniform fading of the lighter colour as a result of sulphone treatment or by both methods; $(d)$ Those of less than $5 \mathrm{~cm}$. diameter; $(e)$ Those on parts of the body not directly visible to the patient, unless he or she lived with a close relative who had observed the progress of the lesion and was available for questioning.

Macules showing some erythema and lack of definition of edge, were not excluded, provided that they were of sufficient size - see $(d)$ above and pallor to be easily seen. These macules, having some of the appearances of tuberculoid and some of lepromatous lesions, are referred to in the Table under 'Classification' as dimorphous $(=\mathrm{D})$.

In practice, this left seventy-one patients with flat or almost flat hypopigmented macules for assessment. With the method of assisted history taking, no patient questioned had to be excluded from the study because of inability to remember how the macule under examination had developed.

\section{Results}

These are shown in the Table. It will be seen that of the I I lesions classified as dimorphous, io occurred in males and only i in a female, whereas of the tuberculoid lesions, 24 occurred in males and 36 in females. In this series of patients selected for the factor of pigment loss, the preponderance of males among those whose tissues show 'lepromatoid' behaviour, and of females among the pure tuberculoid types, is in accord with the findings of Kinnear Brown. ${ }^{4} \mathrm{He}$ found that in Uganda, although the incidence of the disease was very similar in the two sexes, significantly more males suffered from lepromatous leprosy, and more females had tuberculoid or non-lepromatous leprosy. In the present series,

\section{22 Leprosy Review}




\begin{tabular}{|c|c|c|c|c|c|c|c|}
\hline Serial No. & Cilinic & Cilassification & Maturity & $\operatorname{Sex}$ & Onset type & Smear & Inaesthesia \\
\hline I & Angiama & Dimorphous & Adult & Male & 2 & - & o \\
\hline 2 & , & $\mathrm{D}$ & A & $\mathbf{M}$ & 2 & 一 & o \\
\hline 3 & , & $\mathrm{D}$ & A & M & I & - & 2 \\
\hline 4 & , & $\mathrm{D}$ & A & M & I & $\mathrm{E}+\mathrm{Sk}+$ & o \\
\hline 5 & Degema & I) & A & M & 2 & - & o \\
\hline 6 & Edeoha & D) & $\mathrm{A}$ & M & 2 & $\mathrm{E}+-\mathrm{Sk}++$ & -0 \\
\hline 7 & Gokana & $\mathrm{D}$ & A & M & 3 & +- & o \\
\hline 8 & , & $\mathrm{D}$ & A & M & 3 & + & 2 \\
\hline 9 & , & $\mathrm{D}$ & A & M & 2 & + & o \\
\hline IO & Angiama & $\mathrm{D}$ & Child & M & 1 & - & 2 \\
\hline II & Lmuagbai & 1) & $\mathrm{A}$ & Female & 3 & $\mathrm{E}++\mathrm{Sk}+-$ & -0 \\
\hline I 2 & Angiama & Tuberculoid & $\mathrm{A}$ & $\mathrm{M}$ & 2 & - & o \\
\hline I3 & , & $\mathrm{T}$ & $A$ & M & 3 & - & 2 \\
\hline 14 &, & $\mathrm{~T}$ & A & M & 3 & & 2 \\
\hline 15 & , & $\mathrm{T}$ & A & M & I & - & o \\
\hline I 6 & Anyama & $\mathrm{T}$ & A & M & 1 & - & o \\
\hline 17 & ," & $\mathrm{T}$ & A & M & 3 & - & 2 \\
\hline I 8 & Degema & $\mathrm{T}$ & $A$ & M & 2 & & 2 \\
\hline I9 & ,, & $\mathrm{T}$ & A & $\mathrm{M}$ & 3 & - & I \\
\hline 20 & Edeoha & $\mathrm{T}$ & A & M & I & - & 2 \\
\hline $2 \mathrm{I}$ & , & $\mathrm{T}$ & A & M & I & - & 2 \\
\hline 22 & , & $\mathrm{T}$ & $\mathrm{A}$ & M & 3 & - & o \\
\hline 23 & Ekowe & $\mathrm{T}$ & A & M & 3 & - & o \\
\hline 24 & Gokana & $\mathrm{T}$ & A & M & 3 & - & 2 \\
\hline 25 & Isoba & $\mathrm{T}$ & A & M & I & - & 2 \\
\hline 26 & , & $\mathrm{T}$ & A & M & 2 & - & 2 \\
\hline 27 & Okodogu & $\mathrm{T}$ & A & $\mathrm{M}$ & 2 & - & o \\
\hline 28 & Okwuzi & $\mathrm{T}$ & A & M & I & 一 & 1 \\
\hline 29 & Sabagreia & $\mathrm{T}$ & A & M & 2 & - & o \\
\hline 30 & Ubetta & $\mathrm{T}$ & A & M & 1 & & 2 \\
\hline $\begin{array}{l}3 \\
3\end{array}$ & Umuagbai & $\mathrm{T}$ & A & M & 3 & - & 2 \\
\hline 32 & Anyama & $\mathrm{T}$ & C & M & 2 & - & 2 \\
\hline 33 & Degema & $\mathrm{T}$ & C & M & 2 & - & 2 \\
\hline 34 & Ekowe & $\mathrm{T}$ & C & M & 1 & - & o \\
\hline 35 & Tabangh & $\mathrm{T}$ & $\mathrm{C}$ & M & 3 & - & 2 \\
\hline 36 & Amassoma & $\mathrm{T}$ & A & $\mathrm{F}$ & 3 & - & o \\
\hline 37 & , & $\mathrm{T}$ & A & $\mathrm{F}$ & 3 & - & I \\
\hline $3^{8}$ & , & $\mathrm{T}$ & A & $\mathrm{F}$ & 3 & - & o \\
\hline 39 & ", & $\mathrm{T}$ & A & $\mathrm{F}$ & 3 & - & 2 \\
\hline 40 & Angiama & $\mathrm{T}$ & A & $\mathrm{F}$ & 2 & - & o \\
\hline $4^{I}$ & , & $\mathrm{T}$ & A & $\mathrm{F}$ & 3 & - & I \\
\hline 42 & , & $\mathrm{T}$ & A & $\mathrm{F}$ & I & - & o \\
\hline 43 & , & $\mathrm{T}$ & A & $\mathrm{F}$ & 3 & - & o \\
\hline 44 & , & $\mathrm{T}$ & A & $\mathrm{F}$ & 1 & +- & o \\
\hline 45 & ", & $\mathrm{T}$ & $\mathrm{A}$ & $\mathrm{F}$ & 3 & - & I \\
\hline $4^{6}$ & , & $\mathrm{T}$ & A & F & 2 & - & \\
\hline & , & $\mathrm{T}$ & A & $\mathrm{F}$ & I & - & 2 \\
\hline 48 & , & $\mathrm{T}$ & A & $\mathrm{F}$ & I & - & 2 \\
\hline 49 & , & $\mathrm{T}$ & A & $\mathrm{F}$ & 2 & - & o \\
\hline 50 & , & $\mathrm{T}$ & A & $\mathrm{F}$ & I & - & 2 \\
\hline $5^{I}$ & ", & $\mathrm{T}$ & A & $\mathrm{F}$ & 2 & - & 2 \\
\hline $5^{2}$ & Anyama & $\mathrm{T}$ & A & $\mathrm{F}$ & 2 & 一 & 2 \\
\hline 53 & Degema & $\mathrm{T}$ & A & $\mathrm{F}$ & 3 & - & o \\
\hline 54 & , & $\mathrm{T}$ & A & $\mathrm{F}$ & I & - & o \\
\hline
\end{tabular}

The Clinical Dynamics of Pigment Loss I 23 


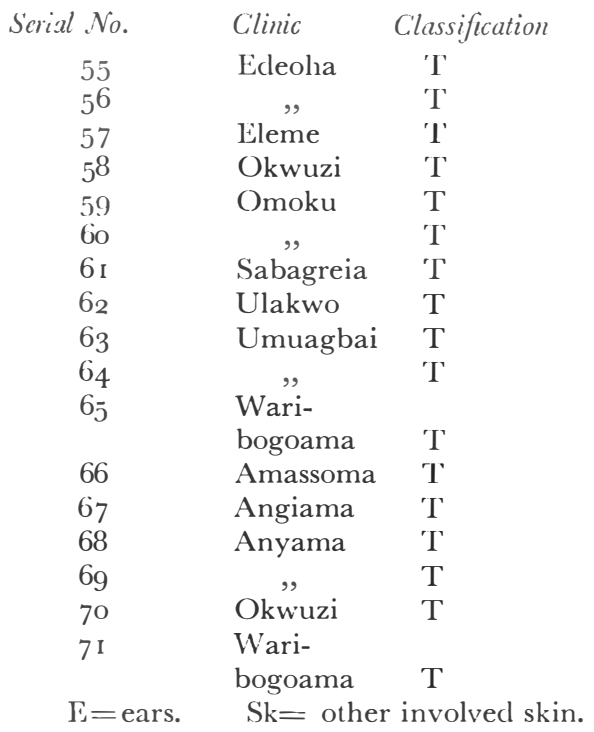

\begin{tabular}{|c|c|c|c|c|}
\hline Maturty & Sex & Onset typse & Smear & Anaesthesia \\
\hline A & $\mathrm{I}$ & I & - & 0 \\
\hline A & I & 1 & - & 2 \\
\hline$\Lambda$ & $\mathrm{F}$ & 3 & 一 & I \\
\hline A & $\mathrm{F}$ & 2 & - & I \\
\hline A & $\mathrm{F}$ & 3 & - & 2 \\
\hline A & F & I & - & 2 \\
\hline A & $\mathrm{F}$ & 3 & - & I \\
\hline A & $F$ & 2 & - & 0 \\
\hline$\Lambda$ & $\mathrm{F}$ & 2 & - & 2 \\
\hline$\Lambda$ & F & 3 & - & o \\
\hline A & $\mathrm{F}$ & I & - & o \\
\hline C & F & 3 & - & o \\
\hline C & $\mathrm{F}$ & 2 & - & 2 \\
\hline C & $\mathrm{F}$ & 3 & 一 & 2 \\
\hline C & $\mathrm{F}$ & 3 & - & I \\
\hline C & $\mathrm{F}$ & I & - & I \\
\hline C & F & 3 & & 2 \\
\hline
\end{tabular}

22 macules were of onset type I ., 2 I of type 2. and 28 of type 3 .

No statistically significant correlations were found between the onset type and any of the other features studied; but it is clear that macules having similar clinical appearance showed differences in development, recognised by the patients, which would be missed by the clinician unless specifically sought.

\section{DIS C U S S I O N}

The underlying cause of pigment loss in leprosy has remained obscure. If it is associated with lepra bacilli at all, it must be only indirectly so, since there is very nearly an inverse relationship between the numbers of bacilli found in the dermis and the degree of hypopigmentation.

Certainly it is associated with an epithelioid and giant cell - or with a rather less specific - type of granuloma, involving the deeper layers of the epidermis. This granuloma, in its turn is assumed to be associated at some time in its evolution, with the presence of lepra bacilli. Neither pigment loss nor nerve damage seems, however, to be a feature of the cytologically tuberculoid, positive response to lepromin.

In lepromin testing, heated bacillary antigen is used, and here it seems reasonable to infer a true cause and effect relationship, the bacilli being destroyed by the granuloma elicited by them, but remaining largely intact in its absence. ${ }^{10}$ With naturally occurring hypopigmented lesions, no such inference is possible. In the present study, the way that macules of type 2., appear, suggests an underlying reservoir of the depigmenting factor becoming effective over a wide area at one time. That there is some association of this factor with lepra bacilli is indicated by the fact that when found, these tend to be located near the periphery of hypopigmented lesions ${ }^{15}$ and may be seen in cells not essentially different from those found in lepromatous tissue. ${ }^{11}$ It is possible therefore, that the association is with a deeper, preceding, rarified, regressing patch of leproma, whose expansion has stopped or almost stopped. It is difficult however, to see how this concept alone could account for the expansion of macules of type I., and particularly of type 3., in which pigment loss evidently increases directly with the increase in the skin area affected by the granuloma, almost certainly, in most cases, in the absence of bacilli.

Could it be that hypopigmentation is caused by the destruction of bacilli by the human host, or by their spontaneous disintegration? Its absence from positive lepromin responses and from resolving lepromata make either of these possibilities unlikely.

One way to account for the present findings would be to suppose that in type 2., macules a submicroscopic self-replicating agent has invaded 
the germinative layer as a large sheet of particles, whereas in macules of types I., and 3., the agent is spreading centrifugally from cell to cell. Melanocytes, we are told ${ }^{12}$ are very numerous in the epidermis and are supplied with a complex system of dendrites that intertwine with, and end on epidermal cells, and supply them with pigment. They are believed to be of neuroectodermal origin, being derived from cells of the embryonic neural crest. They would make an admirable habitat for any sufficiently small living agent proliferating by cell to cell passage. In fact, it is known that many viruses are able to live in cells of epithelia, especially those of the skin, and a viral aetiology has long been suspected in leprosy. ${ }^{16}$

The observation of phage-like particles and 'ghost bodies' by Richards and Wade, ${ }^{22}$ and in vitro comparison of the effects of sunlight on heated and unheated lepra bacilli, ${ }^{6}$ suggested that each bacillus was being affected by a much smaller organism, which, it was postulated, was variably pathogenic to certain tissues of the human host. (It is of interest that intrabacillary ovoid particles of about $30 \mu$ diameter, apparently arising from the cell wall of a lepra bacillus, have been seen under the electron microscope. ${ }^{14}$ In appearance these particles might be taken for virus bodies.). Examination of mixed lesions ${ }^{7}$ pointed to certain aspects of the behaviour of the proposed organism, but it was not at that time thought that it could have an extrabacillary reproductive existence, nor that it could affect skin pigmentation. Recent work, however, appears to support this idea.

In view of the apparently minor direct pathogenicity of lepra bacilli, it seems likely that an immune mechanism could underlie many leprosy lesions, and indeed several workers 2320 have shown serological similarities between leprosy and the so-called auto-immune diseases. There are some however, who consider that these diseases themselves may have an underlying infective aetiology. Thus Pease ${ }^{21}$ considers that auto-immune diseases may be caused by subcellular particles of microbial origin which by a process of degeneration become incapable of independent existence, but which are probably capable of acting as episomes and invading the genetic processes of the mammalian host's cells so that these themselves produce foreign antigens.
The fact that bacteriophages, which in any case are widely believed to have a bacterial origin, may also play a part in disease, has lately received some attention. ${ }^{13} 17 \quad 1819$ Mankiewicz and van Walbeek ${ }^{17}$ were able to produce lysis of a parent strain of tubercle bacillus $\mathrm{H}_{37} \mathrm{Rv}$, by a mutant strain which had been repeatedly exposed to mycobacteriophage DW. The appearances they noted seem to be remarkably similar to those described by Richard and Wade, ${ }^{22}$ and stained preparations of their lysogenic strain, looking like chains of streptococci bear close resemblance to many of the 'granular forms' of lepra bacilli familiar to every leprologist. The lysogenic bacteria did not elicit tuberculin reactions in guinea pigs. Mankiewicz and Béland ${ }^{18}$ have been able to induce 'sarcoid like' lesions in guinea pigs infected simultaneously with mycobacteriophage DS6A and tubercle bacilli, and their findings in such animals also treated with cortisone could serve as a model for the study of lepra reactions in man.

Recently, Mankiewicz ${ }^{19}$ has been able to demonstrate in vitro pathogenicity of bacteriophages that lyse mycobacteria and corynebacteria, for mammalian cells.

A further point of interest concerns the thiosemicarbazones. These, according to Dugeon ${ }^{9}$ provide a link in the development of bacterial and viral chemotherapeutic agents. It is probably no coincidence that different members of this group of compounds have been found effective in the treatment of leprosy ${ }^{8}$ and in the prophylaxis of smallpox. ${ }^{1}$ The well known association between vaccinia and lepra reaction ${ }^{525}$ is at least suggestive of a common defence mechanism against biologically related causes.

We cannot conclude without wondering whether Mycobacterium leprae as a species really exists. Are we perhaps seeing an infected mycobacterium and the relationships of the infecting organism with the cells of the iruman host, as well as with those of the microbial host?

If so, might it be possible to construct 'lepra bacilli' de novo, by infecting cultivable mycobacteria with phages or mammalian viruses? Whatever the answers to these questions - and to others - the accumulation of knowledge of the ecology of very tiny creatures in their natural micro-environments, must lend added impetus to

The Clinical Dynamics of Pigment Loss I 25 
the alteration of much of the terminology of 'leprosy', already begun on humanitarian grounds.

\section{S UMM A R Y}

The development of $7 \mathrm{I}$ hypopigmented flat skin lesions in Nigerian patients, was studied.

The patients were able to recognise three developmental types of lesion, which, on clinical examination, showed no statistically significant affinities in relation to the other features found. It is believed that in skins sensitive to it, pigmentary loss is brought about by extrabacillary proliferation of a subcellular, self-replicating agent initially carried by mycobacteria, rather than by mycobacteria themselves.

\section{A GKNOWLEDGEMENTS}

It is a plcasure to express my thanks to Dr. P. E. Pease, of the Department of Virology and Bacteriology, University of Birmingham Medical School, for her most helpful criticism and advice in the preparation of this paper. Any shortcomings it contains are mine alone.

I am also most grateful to my colleague Mr. J. Bryant, a student of mathematics in the University of Durham, for his analysis of the figures; and to the Leprosy Inspectors and patients of Rivers Province, Eastern Nigeria, for their co-operation.

\section{REFERENCES}

I. BAUER, D. J., St. Vincent, L., Kempe, C. H. and DOWNiE, A.w. (I 963 . Prophylactic treatment of smallpox contacts with N-methylisatin B-thiosemicarbazonc. Lancet, 2, p. 494 .

2. BONOMO, L., DAMmACCO, F. PINTO, L. and BARBieri, G. (1963). Thyroglobulin antibodies in leprosy. Lancet, 2, pp. $807-809$.

3. воNOMO, L., tURsi, A., Trimigliozzi, G. and DAmmacco, F. (1965).L.E. cells and antinuclear factors in leprosy. Brit. Med. 7., 2, pp. 689-69o.

4. BRown, J. A. KINNEAR, (1959). Factors influencing the transmission of leprosy. Trans. R. Soc. trop. Med. Hyg. 53, p. 179 .

5. BRowne, s. G. and Davis, E. m. (1962). Reaction in leprosy precipitated by smallpox vaccination. Leprosy Rev. 33, 4, pp. 252-254.
6. CoRcos, M. G. (1953). Human lepra bacilli exposed to sunlight will retain their acid fastness if they are first heated. Leprosy Rev. 24, 3, pp. 67-70.

7. corcos, м. G. (1964) Mycobacterium leprae: a house divided? Leprosy Rev. 35, 3, pp. $6 \mathrm{I}_{\mathrm{I}} \mathbf{7 7}$.

8. DAvey, T. F. (1964). Leprosy in Theory and Practice, Ed. Cochrane, R. G. and Davey, T. F. John Wright \& Sons. Ltd., Bristol. pp. 395-396.

9. Dudgeon, J. A. (1965). Advances in the treatment of virus diseases. Practitioner, 195, I 168, p. 503.

io FERnANDEZ, J. м. м. (1954). Bacteriologia de la lepra. Investigaciones para dilucidar si el Mycobacterium leprae esta muerto o vivo. Valor del metodo de Ziehl Neelsen. Med. Panamericana, 3. abstr. in Int. 7. Leprosy (1962), 3o, 4, pp. 504-505.

I I. FITE, G. L. (I95I). The pathology and pathogenesis of leprosy. Ann. N.Y. Acad.Sci. 54, i, p. 28.

12. ham, A. W. and Leeson, T. s. ( 1965 ). Histologj. Pitman Medical Publishing Co. Ltd., p. 633.

13. hayes, w. (1964). The Genetics of Bacteria and Their Viruses. Blackwell Scientific Publications, Oxford, p. $55^{\circ}$. I4. IMAEDA, T. ( I962) cited by WADE, H. W. in Undiscussed problems of the bacteriology of tuberculoid and borderline leprosy. Int. 7. Leprosy, 3o, 4, p. 493.

I5. Khanolkar, v. R. (1964). Pathology of leprosy. Leprosy in Theory and Practice. Ed. Cochrane, R. G. and Davey, T. F., John Wright \& Sons Ltd., Bristol, p. 139.

I6. manalang, C. (1931). Significance of findings in biopsy materials from lepers. Philippine Health Service $\mathcal{N} o$. Bull. r1, pp. 633-538, cited by wADE, H. w. in "L" bodies or protoplasts of the leprosy bacillus? (1962). Int. 7. Leprosy, 30, 4 , pp. $501-503$.

i 7. MANkiewicz, E. and van Walbeek, m. (i962). Mycobacteriophages. Their role in tuberculosis and sarcoidosis. Arch. Env. Hlth. (Amer. Med. Assn.), 5, pp. 1 22-1 28.

I8. MANKIEWICZ, E. and BÉLAND, J. (ig64). The role of mycobacteriophages and of cortisone in experimental tuberculosis and sarcoidosis. Amer. Rev. Resp. Dis., 89, 5, pp. 707-720.

i9. Mankiewicz, E. (1965). Bacteriophages that lyse mycobacteria and corynebacteria, and show cytopathogenic effect on tissue cultures of renal cells of "Cercopithecus aethiops". Canad. Med. Assn. J., 92, pp. 31-33.

20. matthews, L. J. and trautman, J. R. ( 1965 ). Clinical and serological profiles in leprosy. Lancet, 2, pp. 9 і 5-9 8. 2 I. PEASE, P. E. (1965). L-Forms, Episomes and Auto-immune Disease. E. \& S. Livingstone Ltd., Edinburgh and London, p. 36 .

22. R.Chards, O. w. and wade, H. w. (i 949). Application of phase microscopy to the examination of the leprosy bacillus. Memoria del 5 Congr. Int. d: la Lepra, i 948, La Habana, Cuba, p. 5 ig.

23. Rogers, L. and muir, E. (1946). Leprosy, Bristol: John Wright \& Sons Ltd., p. 172.

24. ibid. p. 179 .

25. ibid. p. 87 . 